\title{
SULFUR- AND STRONTIUM-ISOTOPIC GEOCHEMISTRY OF CELESTITE, BARITE AND GYPSUM FROM THE MESOZOIC BASINS OF NORTH- EASTERN MEXICO
}

\author{
STEPHEN E. KESLER and LOIS M. JONES \\ Department of Geological Sciences, University of Michigan, Ann Arbor, MI 48109 (U.S.A.) \\ Research and Development Department, CONOCO, Inc., Ponca City, OK 74601 (U.S.A.)
}

(Received April 14, 1980; revised and accepted October 9, 1980)

\section{ABSTRACT}

Kesler, S.E. and Jones, L.M., 1981. Sulfur- and strontium-isotopic geochemistry of celestite, barite and gypsum from the Mesozoic basins of northeastern Mexico. Chem. Geol., 31: $211-224$

The Mesozoic sedimentary basin of northern Mexico contains large limestone-hosted stratiform "mantos" of celestite and barite that appear to have formed by carbonate replacement. We have measured the isotopic compositions of sulfur and strontium in these mantos in order to determine whether they formed by diagenetic processes and, if so, what fraction of the diagenetically released $\mathrm{Sr}$ is fixed in celestite deposits. S- and $\mathrm{Sr}$-isotopic analyses of gypsum from layers in the limestone confirm its Cretaceous sedimentary origin. Isotopic compositions of most celestite and barite differ from values observed for the gypsum. Division of the deposits into two geologically and geochemically distinct groups shows that there is a general positive correlation between $\delta^{34} \mathrm{~S}$ and ${ }^{87} \mathrm{Sr} /{ }^{86} \mathrm{Sr}$ compositions of celestite and barite in the two systems, with celestite containing lighter $\mathrm{S}$ and less radiogenic $\mathrm{Sr}$ in both groups of deposits. Less radiogenic $\mathrm{Sr}$ in the celestite probably came from nearby Cretaceous limestones. More radiogenic $\mathrm{Sr}$, which is found largely in the barite, probably came from basement-derived arkoses in the Cretaceous basin. Sulfur was derived from evaporites in one deposit group and from some other lighter source, perhaps coal or petroleum, in the other. These isotopic constraints, considered in the light of available solubility data, require that at least two distinct solutions existed and mixed locally during formation of the celestite and barite mantos. No more than $10 \%$ of the diagenetically-released $\mathrm{Sr}$ is concentrated in the celestite deposits.

\section{INTRODUCTION}

Although large amounts of strontium can be released during diagenesis of carbonate rocks (Kinsman, 1969; Butler, 1973), little is known about the fate of this Sr. For instance, the Sr might be dispersed into seawater or concentrated into accumulations of celestite $\left(\mathrm{SrSO}_{4}\right)$ or strontianite $\left(\mathrm{SrCO}_{3}\right)$. Determination of which of these possibilities prevails could provide information on the mass balance of $\mathrm{Sr}$ in seawater-carbonate rock systems, as well as on the timing and pattern of fluid flow during carbonate diagenesis. The 
Mesozoic sedimentary basin of northeastern Mexico (Fig. 1) provides an opportunity to study this problem because it contains some of the largest celestite deposits in the world (Fulton, 1975). These celestite deposits are strata-bound "mantos" that formed by replacement of pre-existing sedimentary rock. Barite deposits of similar characteristics are found in the basin, and gypsum horizons of evaporitic sedimentary origin are also wide-spread. In order to place constraints on the origin of these mantos, we have measured the isotopic composition of $\mathrm{S}$ and $\mathrm{Sr}$ in celestite, barite and sedimentary gypsum.

The ${ }^{87} \mathrm{Sr} /{ }^{86} \mathrm{Sr}$ ratios were determined at Conoco, Inc., on a Varian ${ }^{(3)} \mathrm{MAT}$ 260 thermal ionization mass spectrometer. A rhenium double-filament arrangement was used in the evaporation-ionization process. Measurements of the isotopic composition were made by using double Faraday collectors. The analyses normally consisted of five sets of ten runs, and each recorded run is the average of 100 measurements. The standard deviation for the analyses was usually within $\pm 0.00003(2 \sigma)$. The $\delta^{34} \mathrm{~S}$ ratios were determined by Geochron Laboratories. Most of the celestite and gypsum measurements were made on a AEI ${ }^{\circledR}$-MS-20 instrument. Most of the barite measurements were

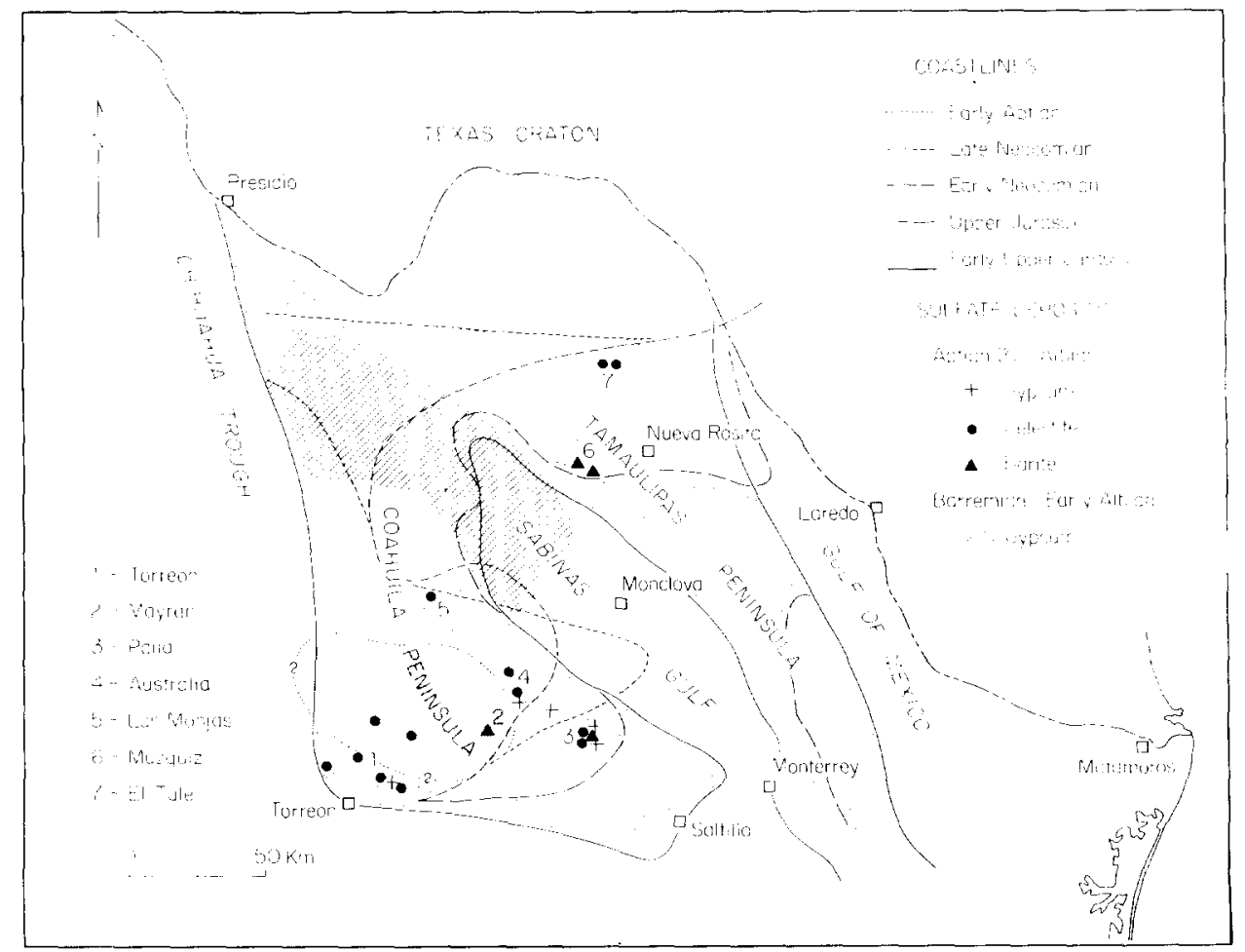

Fig. 1. Paleogeographic map of the Mesozoic sedimentary basin of northeastern Mexico generalized from Kellum et al. (1936), Humphrey (1956) and Charleston (1975), showing distribution of gypsum, celestite and barite. 
made on a VG-Micromass ${ }^{\oplus} 602-\mathrm{D}$. All analyses used $\mathrm{SO}_{2}$ gas prepared by converting the sulfur in sulfate minerals to $\mathrm{H}_{2} \mathrm{~S}$, reacting this with cadmium acetate to precipitate cadmium sulfide and combusting this in flowing oxygen at $1300^{\circ} \mathrm{C}$ to produce $\mathrm{SO}_{2}$ (Thode et al., 1961). Overall analytical repeatability for the sulfate analyses is commonly $0.3 \%$ or less.

\section{REGIONAL STRATIGRAPHIC SETTING OF THE SULFATE DEPOSITS}

The celestite, barite and gypsum deposits of northeastern Mexico are found in a thick Mesozoic sedimentary sequence (Table I) that was deposited on a topographically irregular basement of Paleozoic and Precambrian(?) rock (Denison et al., 1970). The dominant positive topographic elements in the basin were the Tamaulipas and Coahuila peninsulas (Kellum et al., 1936; Humphrey, 1956), which were probably formed by block faulting (Fig. 1). In early Mesozoic time, these peninsulas were bordered by the Chihuahua

\section{TABLE I}

Generalized stratigraphic column of the Mesozoic sedimentary basin of northeastern Mexico [largely after Humphrey (1956) and Conklin and Moore (1977)] showing stratigraphic range of known celestite and barite mantos for each of the seven areas of mantos in Fig. 1

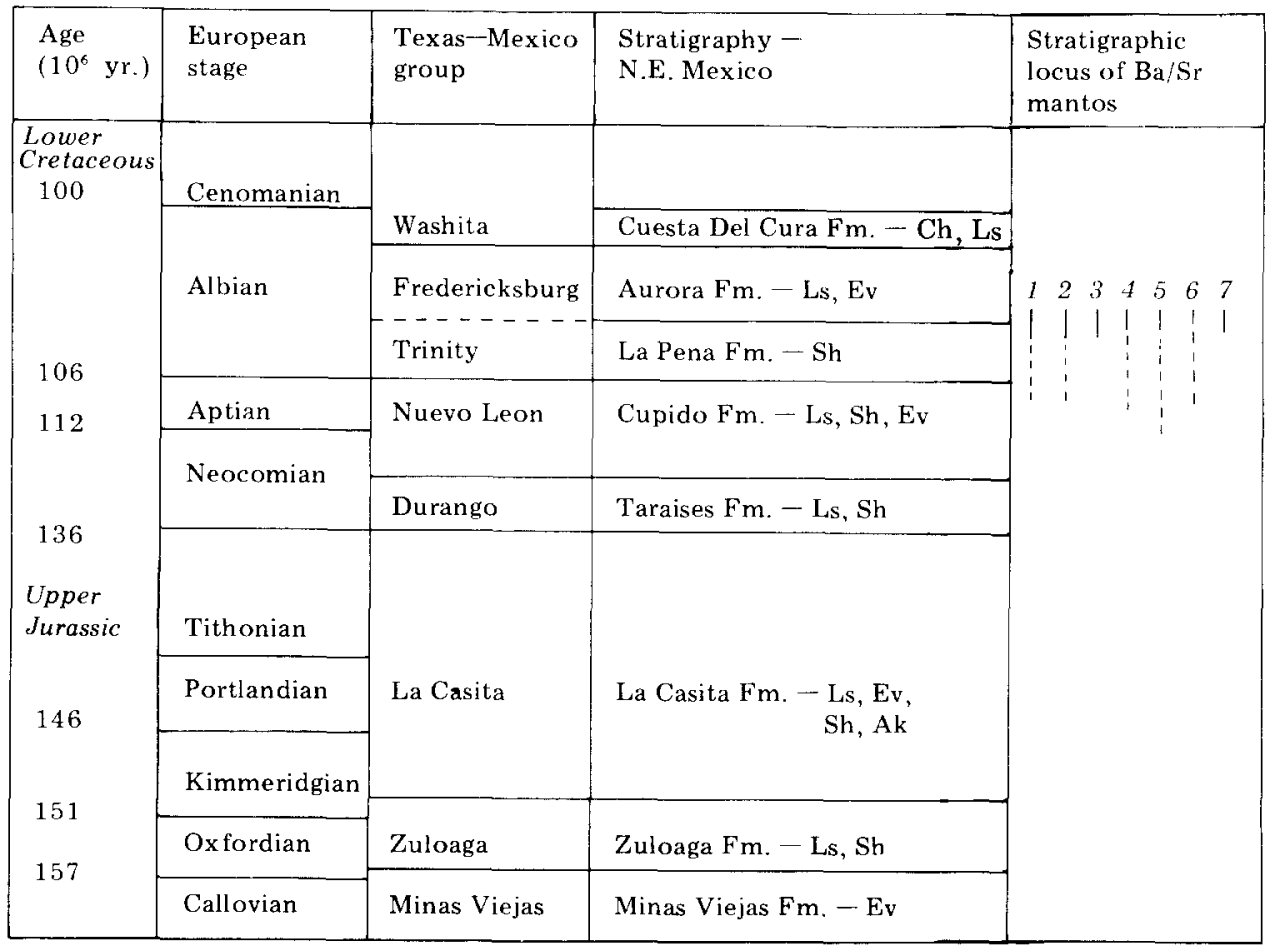

$\mathrm{Ak}=\operatorname{arkoses} ; \mathrm{Ch}=$ chert $; \mathrm{Ev}=$ evaporites $; \mathrm{Ls}=$ limestones $;$ and $\mathrm{Sh}=$ shales. 
trough, the Sabinas Gulf and the early Gulf of Mexico (Fig. 1), which merged to the south to form the Mexican Sea (Humphrey, 1956, p. 31). Marine transgression flooded the Tamaulipas peninsula by early Neocomian time (see Fig. 1 and Table I), whereas the Coahuila peninsula persisted as an island into early Aptian time.

The oldest exposed unit is the Jurassic Minas Viejas evaporite (Table I), which is found in the core of diapirs formed by folding of the sediments deposited in the Sabinas Gulf (Weidie and Martinez, 1970, p. 656). Subsequent late Jurassic and early Neocomian sedimentation (Table I) was characterized by facies variations related to proximity of the peninsulas. The Taraises formation, for instance, contains clastic wedges known as the Patula and San Marcos arkoses (Krutak, 1965; Charleston, 1975) that were shed into the Sabinas Gulf. Continued transgression in Cupido time produced a major reef system that extended northward from Monterrey into Texas (Conklin and Moore, 1977; Wilson and Pialli, 1977) and backreef evaporites, shown by the stippled zone in Fig. 1. By early Aurora time, the Cupido reef system was submerged and a less well-delineated system of reefs and backreef evaporites developed around and on the Aptian island at the south end of the Coahuila peninsula (Kellum et al., 1936; de Cserna, 1971; Charleston, 1975). In late Albian (Aurora) time, the area was fully submerged and deep-water pelagic lime mudstones were deposited over all of northeastern Mexico.

Deformation of these sediments began in early Cretaceous time as western Mexico underwent igneous activity (de Cserna, 1971) and shed clastic sediments eastward that covered the Upper Cretaceous sediments. The culmination of deformation took place in early Eocene time (de Cserna, 1956, 1971) when sediments deposited in these basins were folded, thrust eastward, and penetrated locally by diapiric intrusions of Minas Viejas salt and gypsum (de Cserna, 1956; Weidie and Martinez, 1970). Sediments overlying the former basement highs were less strongly deformed and remain as large brachyanticlinal mountain ranges (Kellum et al., 1936).

It should be clear from this discussion and the stratigraphic descriptions in Table I that, although evaporitic gypsum is wide-spread in the Mesozoic sedimentary basin of northeastern Mexico, the celestite and barite mantos exhibit a much more restricted distribution. To date, almost all known deposits have been found in the late Albian Aurora Formation or its equivalents, where they overlie the old Coahuila or Tamaulipas peninsulas (Fig. 1). Carbonate rocks hosting the celestite and barite mantos, especially on the Aptian Coahuila island, contain rudist bioherms, stromatolites, mud-cracks and thin $(2-20 \mathrm{~m})$ gypsum horizons characteristic of a backreef lagoonal environment. Deeper-water facies of the Aurora Formation are not presently known to contain celestite or barite mantos. 

MANTOS

The celestite and barite deposits are essentially stratabound mantos that measure up to $4 \mathrm{~m}$ thick and $1 \mathrm{~km}$ long. In the Paila region (Fig. 1) as many as ten celestite mantos have been observed in a stratigraphic interval measuring $\sim 100 \mathrm{~m}$ thick. In most areas there are at least two "stacked" mantos, which are separated by a $0.1-0.5-\mathrm{m}$ layer of micritic limestone (Salas, 1973). Individual mantos tend to be confined to a single stratigraphic horizon, and in any one district the same horizon can be mineralized locally for as much as $20 \mathrm{~km}$. Barite and celestite are not present in the same mantos, and Paila is the only district in which mantos of both types are present. Here the celestite mantos occur in a northeast-trending zone to the northwest of the barite mantos. Although the edge of the old Coahuila Island trends northwest in this area (Fig. 1), local stratigraphic data are not adequate to test for lithologic controls on this apparent celestite-barite zonation.

Most celestite mantos consist of medium- to coarse-grained $(1 \mathrm{~cm})$ white celestite with varying amounts of unreplaced limestone and dolomite (Salas, 1973). In very pure mantos, some "vugs" are lined with bladed celestite crystals as much as $10 \mathrm{~cm}$ in length. Minor minerals seen in the celestite mantos include native sulfur, fluorite and gypsum, all of which formed after celestite. Petroleum material is not common in these deposits. The barite mantos are similar mineralogically but exhibit generally finer grain size.

That the mantos formed by replacement of pre-existing wallrock is clearly indicated by the presence in the mantos of chert nodules and what appears to be original crossbedding. Salas (1973) and Rickman (1977) concluded that the celestite mantos in the Paila area formed by replacement of limestone. If this is the case, the crossbeds suggest that the limestone was deposited as a backreef dune. Where the contact between limestone wallrocks and celestite or barite can be seen, it is apparent that the limestone was being replaced. Bedded gypsum is present a few meters below the celestite in the Australia, Paila and Torreon areas, but it is not found at the same stratigraphic horizon as the celestite.

Although most of the celestite and barite mantos are found in areas that lack evidence of post-diagenetic hydrothermal activity, the Paila and El Tule areas (Fig. 1) contain abundant vein-and-manto fluorite mineralization. Inasmuch as the fluorite mineralization is a product of Oligocene igneous activity (Kesler, 1977), this association raises the possibility that the celestite and barite mantos are also Oligocene in age. We do not consider this to be likely because the fluorite can be shown to be younger in outcrop. For instance, at Paila the celestite mantos are cut by fluorite veins (Salas, 1973, fig. 2) and at El Tule the fluorite appears to have grown below pre-existing celestite mantos (Temple and Grogan, 1963, p. 1045). Furthermore, fluid inclusions in the celestite contain single-phase, very low-temperature liquids, whereas those in the fluorite homogenize at $100^{\circ} \mathrm{C}$ or more (Kesler, 1977; Rickman, 1977). 
Observations controlling the relative ages of the fluorite and barite are less certain, however. The two minerals occur together only in the Paila area where all known barite mantos have at least some fluorite overgrowths, whereas the celestite mantos do not. Barite is also found in some veins with fluorite. Fluid inclusions are not visible in the barite. On the basis of these observations, and the relatively systematic spatial zoning of barite and celestite mantos at Paila, we consider it likely that the barite mantos are coeval with the celestite mantos. The barite veins, on the other hand, are considered to be related to the Oligocene fluorite mineralization. Accordingly, only barite mantos from Paila have been included in the isotopic studies discussed below.

\section{ISOTOPIC COMPOSITION OF THE SULFATE DEPOSITS}

\section{Introduction}

The ${ }^{34} \mathrm{~S}$ composition of sulfate minerals is governed by the bulk isotopic composition of $\mathrm{S}$ in the depositing system and by the relative abundances of S-bearing species in the system, which depends on parameters such as temperature and $f_{\mathrm{O}_{2}}$ (Ohmoto, 1972). For gypsum, the depositing medium was seawater, in which the sulfur is present as sulfate. Because none of the celestite and barite deposits coexist with sulfide minerals, it is likely that sulfate was the dominant sulfur species in their depositional system, also. The gypsum was deposited at $\sim 25^{\circ} \mathrm{C}$, and the previously-mentioned fluid-inclusion data indicate that the celestite (and probably the barite) were deposited at similarly low temperatures. Isotopic partitioning between gypsum and brine at these temperatures will be less than $2 \%$ with slight enrichment of $\delta^{34} \mathrm{~S}$ in gypsum (Thode and Monster, 1965). The experimental data of Kusakabe and Robinson (1977) suggest that barite forming from the same brines will be depleted in ${ }^{34} \mathrm{~S}$ by at least $5 \%$ in comparison to gypsum. Data are not available for celestite, but it would probably exhibit intermediate fractionation effects.

The ${ }^{87} \mathrm{Sr} /{ }^{86} \mathrm{Sr}$ composition of a mineral should reflect the ${ }^{87} \mathrm{Sr} /{ }^{86} \mathrm{Sr}$ composition of its parent brine unless it has undergone later (e.g., diagenetic) exchange with solutions having a different ${ }^{87} \mathrm{Sr} /{ }^{86} \mathrm{Sr}$ ratio, or has been enriched in ${ }^{87} \mathrm{Sr}$ by decay of ${ }^{87} \mathrm{Rb}$. Such effects are unlikely in this study, because diagenesis of a soluble mineral such as gypsum would cause it to dissolve and would have little effect on relatively insoluble minerals such as celestite and barite. Crystal chemical considerations and analytical checks indicate that $\mathrm{Rb} / \mathrm{Sr}$ ratios in these minerals are too low for ${ }^{87} \mathrm{Rb}$ to have produced significant amounts of ${ }^{87} \mathrm{Sr}$. Thus, the present-day ${ }^{87} \mathrm{Sr} /{ }^{86} \mathrm{Sr}$ ratio of these minerals is essentially the same as their original ratio.

\section{Sulfur isotopic data}

Isotopic analyses of gypsum from the Aptian-Albian units range from +14 to $+17 \%$ (Table II, Fig. 2 ). These values agree well with the composition- 
TABLE II

Sulfur- and strontium-isotopic compositions of sulfate minerals from the Mesozoic sedimentary basin of northeastern Mexico

\begin{tabular}{|c|c|c|c|c|c|}
\hline $\begin{array}{l}\text { cf. } \\
\text { Fig. } 1\end{array}$ & District & Mineral & $\begin{array}{l}\text { Sample } \\
\text { No. }\end{array}$ & $\begin{array}{l}\delta^{34} \mathrm{~S} \\
(\%)\end{array}$ & ${ }^{87} \mathrm{Sr} /{ }^{86} \mathrm{Sr}^{* 1}( \pm 2 \sigma)$ \\
\hline 1 & Torreon & $\begin{array}{l}\text { gypsum } \\
\text { celestite } \\
\text { celestite } \\
\text { celestite } \\
\text { celestite }\end{array}$ & $\begin{array}{l}\text { II-21-4 } \\
\text { II-21-5 } \\
\text { MX-9-TX } \\
\text { M-76-4-LD } \\
\text { M-76-7-LG } \\
\text { M-76-9-SDV }\end{array}$ & $\begin{array}{l}+13.2 \\
+14.9 \\
- \\
+17.9 \\
+16.8 \\
+17.2\end{array}$ & $\begin{array}{l}0.70752 \pm 0.00005 \\
0.70752 \pm 0.00003 \\
0.70767 \pm 0.00006 \\
0.70766 \pm 0.00005 \\
0.70762 \pm 0.00004 \\
0.70739 \pm 0.00008\end{array}$ \\
\hline 2 & Mayran & barite & CEP & - & $0.70770 \pm 0.00004$ \\
\hline 3 & Paila & $\begin{array}{l}\text { gypsum } \\
\text { celestite } \\
\text { celestite } \\
\text { celestite } \\
\text { celestite } \\
\text { barite } \\
\text { barite } \\
\text { barite } \\
\text { barite }\end{array}$ & $\begin{array}{l}\text { DDH102 } \\
\text { M-SAN } \\
\text { MX-24-SA } \\
\text { M-B } \\
\text { M-CMP } \\
\text { M-77-F-8 } \\
\text { CVB } \\
\text { CAB } \\
\text { CVS- } 1\end{array}$ & $\begin{array}{l}+16.4 \\
+17.7 \\
+18.0 \\
+17.2 \\
+18.2 \\
+16.8 \\
+34.2 \\
+32.1 \\
+38.3\end{array}$ & $\begin{array}{l}0.70761 \pm 0.00005 \\
0.70766 \pm 0.00006 \\
0.70755 \pm 0.00003 \\
0.70767 \pm 0.00003 \\
0.70763 \pm 0.00003 \\
0.70782 \pm 0.00005 \\
0.70800 \pm 0.00004 \\
0.70938 \pm 0.00004 \\
0.70784 \pm 0.00003\end{array}$ \\
\hline 4 & Australia & $\begin{array}{l}\text { celestite } \\
\text { celestite }\end{array}$ & $\begin{array}{l}\text { M-AUS } \\
\text { MS- } 13\end{array}$ & $\begin{array}{l}+16.3 \\
+17.0\end{array}$ & $\begin{array}{l}0.70765 \pm 0.00007 \\
0.70756 \pm 0.00003\end{array}$ \\
\hline 5 & Las Monjas & celestite & MX-5-A & +13.6 & $0.70776 \pm 0.00004$ \\
\hline 6 & Muzquiz & $\begin{array}{l}\text { barite } \\
\text { barite } \\
\text { barite }\end{array}$ & $\begin{array}{l}25-1-\mathrm{LP} \\
26-\mathrm{B}-1-\mathrm{P} \\
24-1-\mathrm{LC}\end{array}$ & $\begin{array}{r}- \\
+15.4 \\
+9.1\end{array}$ & $\begin{array}{l}0.70889 \pm 0.00002 \\
0.70847 \pm 0.00004 \\
0.70877 \pm 0.00006\end{array}$ \\
\hline 7 & El Tule & $\begin{array}{l}\text { celestite } \\
\text { celestite }\end{array}$ & $\begin{array}{l}63-3 \\
33-14\end{array}$ & $\begin{array}{l}+6.4^{* 2} \\
+13.2^{* 2}\end{array}$ & $\begin{array}{l}0.70768 \pm 0.00006 \\
0.70789 \pm 0.00005\end{array}$ \\
\hline
\end{tabular}

${ }^{* 1}$ Normalized to ${ }^{86} \mathrm{Sr} /{ }^{88} \mathrm{Sr}=0.11940$.

NBS $987 \mathrm{SrCO}_{3}$ Interlaboratory Standard, ${ }^{87} \mathrm{Sr} /{ }^{86} \mathrm{Sr}=0.71031 \pm 0.00002(20)$.

$N=8$.

${ }^{* 2}$ From Kesler (1977, table 5).

al range indicated for Lower Cretaceous marine sulfate (Claypool et al., 1980). The celestite data cluster around a well-defined peak at $\sim 17.5 \%$, with several values extending to lighter compositions. Multiple analyses from the Paila, Torreon and Australia areas indicate that the celestites in these districts have homogeneous and similar $\delta^{34} \mathrm{~S}$ compositions. Note also that the $\delta^{34} \mathrm{~S}$-values for both the Paila and Torreon celestites are 1-2\%o higher than gypsum from the same area. The two analyses of El Tule celestite differ from the PailaTorreon-Australia, average, and from each other. The barite data exhibit a wider spread than the gypsum and celestite data (Fig. 2), although both districts contain samples that are compositionally similar to the celestite maxi- 

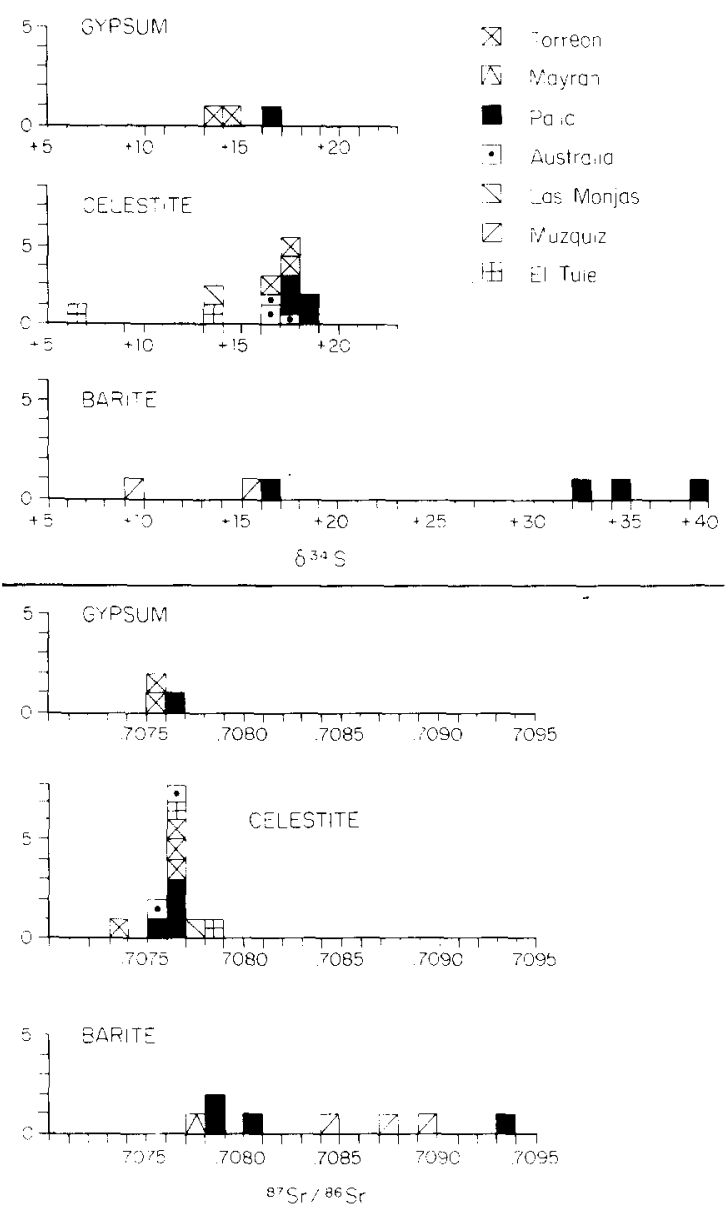

Fig. 2. Histograms of sulfur- and strontium-isotope compositions of gypsum, celestite and barite from several localities in the early Albian carbonate rocks of northeastern Mexico. See Fig. 1 for location of areas.

mum. Furthermore, neither of the barite districts exhibits compositional homogeneity and the Muzquiz district exhibits unusually low $\delta^{34} \mathrm{~S}$-values sim. ilar to those seen in the nearby El Tule celestite district.

\section{Strontium isotopic data}

S-isotopic compositions for gypsum from the Paila and Torreon areas (Table II, Fig. 2) cluster around 0.7075 . This value agrees very well with the values of Peterman et al. (1970), Dasch and Biscaye (1971), and Veizer and Compston (1974) for Aptian-Albian limestones and fossils. L.M. Jones and coworkers (unpublished data, 1979, on fluorite deposits and limestone wallrock) have obtained essentially similar values for Aptian-Albian limestones 
in northeastern Mexico. Data obtained for the celestite (Table II) cluster around 0.70765 , which is essentially the same as the gypsum average. Multiple samples from Paila, Torreon and Australia exhibit strong similarities, whereas the two El Tule analyses exhibit a relatively large spread (Fig. 2). The barite data range from 0.7077 to 0.7094 , an enormous spread when compared to the gypsum and celestite. Neither the Paila nor the Muzquiz data appear to be homogeneous and none of the values coincides with the gypsum average.

\section{Interpretation of the isotopic data}

The barite and celestite deposits in this study can be divided into two different geologic systems: the El Tule-Muzquiz system on the northern Tamaulipas high and the remaining deposits around the Coahuila island (Fig. 1). Fig. 3, which illustrates covariance of our S- and Sr-isotopic data, suggests that barite and celestite in the Coahuila island system have higher $\delta^{34} \mathrm{~S}$-values for any specific ${ }^{87} \mathrm{Sr} /{ }^{86} \mathrm{Sr}$-value than do celestite and barite in the Tamaulipas system. It appears, therefore, that the geochemical evolution of these systems should be considered separately.

The Coahuila island system can be evaluated more completely because we have measured the isotopic composition of sedimentary gypsum in that system. Note in Fig. 3 that the ${ }^{87} \mathrm{Sr} /{ }^{86} \mathrm{Sr}$ compositions of the gypsum and

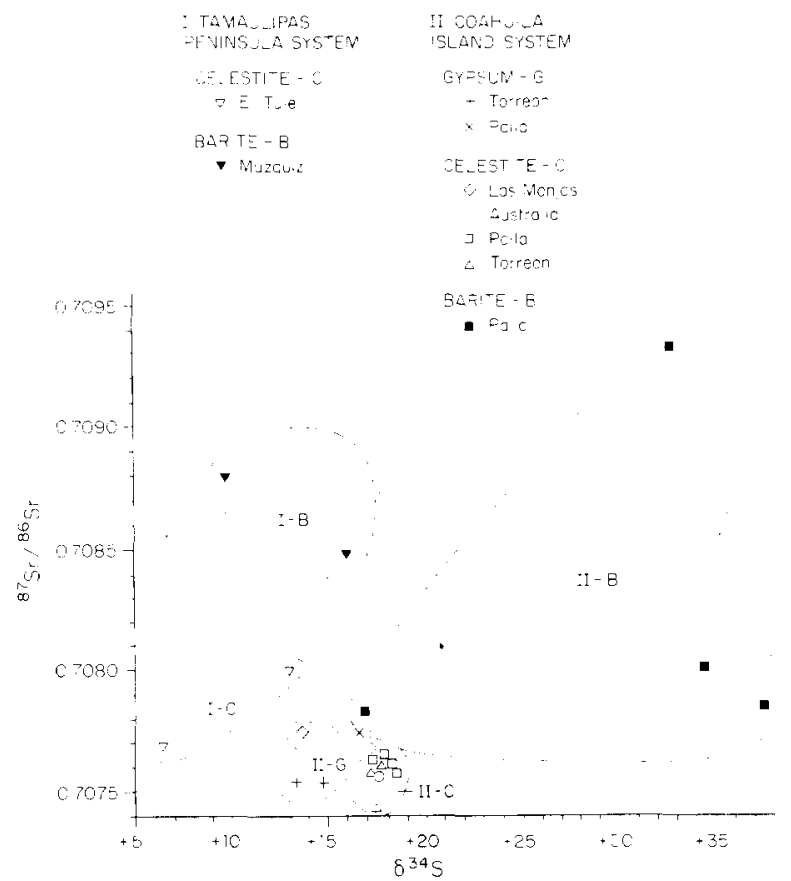

Fig. 3. Variations of ${ }^{87} \mathrm{Sr} /{ }^{86} \mathrm{Sr}$ vs. $\delta^{34} \mathrm{~S}$ for gypsum, celestite and barite from early Albian carbonate rocks in northeastern Mexico. 
celestite are sufficiently similar that the Sr could have been derived directly from the limestones or gypsum. The differing $\delta^{34} \mathrm{~S}$ compositions of the celestite and the gypsum in the Paila and Torreon areas require a more complex explanation, however. We do not think that this difference reflects differing sources for sulfate in the gypsum and celestite. For one thing, no other source of sulfate is known within tens to hundreds of kilometers (Fig. 1). Secondly, these more distant, older gypsum deposits appear to be lighter than $\sim+15 \%$, according to our reconnaissance analyses, which will be published in a separate study. It is most likely that the difference results from inorganic fractionation between celestite and dissolved sulfate derived from local gypsum or from limited enrichment of gypsum sulfate in ${ }^{34} \mathrm{~S}$ by bacterial reduction in a system where the sulfate reservoir was not "infinite" (Faure, 1978, pp. 403--406).

In contrast to the celestite, the barite in the Coahuila island system was deposited from solutions in which both the S- and Sr-isotopic compositions differed from the gypsum values. The magnitude of the $\delta^{34} \mathrm{~S}$ change seems to require a process such as bacterial sulfate reduction and the variability of the barite $\delta^{34} \mathrm{~S}$ compositions suggests that this process was relatively extensive. Although marine sulfate and gypsum appear to be the most reasonable sources for the $\mathrm{S}$ in the barite, marine $\mathrm{Sr}$ does not have the appropriate composition. For example, carbonates of Mesozoic age do not have ${ }^{87} \mathrm{Sr} /{ }^{86} \mathrm{Sr}$ ratios greater than 0.7085 (Veizer and Compston, 1974), whereas the barite exhibits ratios as high as 0.7094 . Thus, some other source must be sought for the unusually radiogenic $\mathrm{Sr}$ in the barite. The most likely possibility is the previouslymentioned Early Cretaceous Patula arkose wedge that borders the Coahuila peninsula on the east (Krutak, 1965). This unit contains clastic material derived from the Paleozoic and Precambrian(?) basement of the Coahuila peninsula, which Denison et al. (1970) have shown to include relatively abundant radiogenic ${ }^{87} \mathrm{Sr}$. This material is preferable because diagenetic decomposition of feldspars in the arkose provides a much more likely source for the $\mathrm{Ba}$ that does diagenesis of Ba-poor carbonate rock (see Parker, 1967, table 19).

The Tamaulipas peninsula system shows both important similarities and differences to the Coahuila island system. For one thing, the limited available data indicate that the barite in both systems contains generally more radiogenic $\mathrm{Sr}$ and heavier $\mathrm{S}$ than the celestite. Among the differences are: (1) the celestite, as well as the barite, shows isotopic heterogeneity for both $\mathrm{S}$ and $\mathrm{Sr}$; (2) the $S$ in the Tamaulipas system is generally lighter in isotopic composition; and (3) there is no evaporite gypsum with compositions at the lower left of the Tamaulipas S-Sr field such as is present for the Coahuila island data (Fig. 3). The first point can be accounted for by processes similar to those used to explain the Coahuila island system, with more extensive bacterial sulfate reduction and involvement of greater amounts of Sr from the San Marcos arkose, which borders the Tamaulipas peninsula on the west. Thus, the celestite-forming part of the Tamaulipas system (El Tule) was probably not a simple limestone-leaching process like that in the Coahuila system. Points (2) and (3) are related and converge on the isotopic composition of the parent 
sulfate for the system. By analogy with the Coahuila island system, the original sulfate in the Tamaulipas system would be predicted to have an isotopic composition of $\sim 0-5 \%$. Evaporates of this composition apparently do not exist (Claypool et al., 1980), although this range is typical of some reduced forms of sulfur in crude oil, coal and native sulfur deposits as well as igneous rocks and sulfide ore deposits (Faure, 1978, pp. 406-413). Coal is widespread in the Sabinas basin (Fig. 1) and crude oil is found in trace amounts in most of the Mesozoic carbonate rocks. There are no sizeable reservoirs of igneous or sulfide ore sulfur in the area. Thus the sulfate in the Tamaulipas system could have been derived by partial oxidation of reduced sulfur in coal or crude oil in the Sabinas basin, although this possibility clearly requires further testing.

\section{Mass balance of strontium}

Recognition that most of the $\mathrm{Sr}$ in the celestite deposits is derived from local carbonate sources permits an estimate of the mass balance of Sr during diagenesis of the system. The Paila celestite district, which is by far the best known in the area, is estimated to contain at least ten mantos measuring $\sim 1 \times 1 \mathrm{~km}$ in horizontal dimensions and $1 \mathrm{~m}$ thick. It seems geologically reasonable to us that at least ten such celestite districts are present on the old Coahuila island (Fig. 1), and this amounts to $\sim 0.2 \cdot 10^{15} \mathrm{~kg} \mathrm{Sr}$. Estimates of the available $\mathrm{Sr}$ in the carbonate rocks of the mineralized area of the Coahuila island system range from a maximum of a $5000 \mathrm{~km}^{2}$ area (see Fig. 1) with a $1 \mathrm{~km}$ thickness of carbonate rock containing $5000 \mathrm{ppm} \mathrm{Sr}\left(75 \cdot 10^{15} \mathrm{~kg} \mathrm{Sr}\right)$ to a similar area with a $100 \mathrm{~m}$ thickness of carbonate rock containing $2000 \mathrm{ppm}$ $\mathrm{Sr}\left(3 \cdot 10^{15} \mathrm{~kg} \mathrm{Sr}\right)$. If about two-thirds of this $\mathrm{Sr}$ were released during diagenesis, this would amount to $5 \cdot 10^{16}$ and $2 \cdot 10^{15} \mathrm{~kg} \mathrm{Sr}$, respectively. Thus, between 0.4 and $10 \%$ of the available $\mathrm{Sr}$ in the Coahuila island system might have been trapped in the source region as celestite. Presumably, the rest escaped into the Cretaceous sea.

\section{Speculations on the origin of the celestite and barite deposits}

Solubility data summarized by Strübel (1967) show that celestite will be dissolved by cooling of a hydrothermal solution between $\sim 300^{\circ} \mathrm{C}$ and $0^{\circ} \mathrm{C}$, regardless of the salinity of the solution. In contrast, Blount (1977) has shown that cooling solutions of any salinity from $100^{\circ}$ to $0^{\circ} \mathrm{C}$ will precipitate barite. Isothermal dilution by pure water will not cause deposition of either mineral. Mixing of Sr- and Ba-bearing solutions with sulfate-bearing solutions can cause deposition, as can oxidation of reduced $\mathrm{S}$ in a solution containing $\mathrm{Ba}$ or Sr. The absence of any sulfide minerals in or around the celestite and barite mantos, however, suggests that reduced sulfur was not abundant in these solutions. Thus, any fluid mixing must have involved $\mathrm{Ba}-\mathrm{Sr}$ brines and sulfate brines. 
These observations provide useful limits for any model proposed to account for the celestite and barite deposits discussed here. For example, a basinal brine from the arkose zone that contained small amounts of $\mathrm{Ba}, \mathrm{Sr}$ and $\mathrm{SO}_{4}$, would deposit barite as it cooled. It would not deposit celestite, however, unless it mixed with a second solution containing either $\mathrm{SO}_{4}$ or $\mathrm{Sr}$. Thus, there is no simple way to deposit both barite and celestite from the same solution without cooling it and then re-heating it, which is very unlikely. The next possibility, that of mixing between two solutions, also fails to account for the fact that the celestite and barite in both systems have different S- and Srisotopic compositions. Thus, for the Coahuila island system, the only reasonable model that can account for the isotopic data in the context of the solubility constraints is one in which the celestite originated by mixing between two locally derived solutions as proposed by Rickman (1977), whereas the barite formed by cooling of a solution carrying $\mathrm{Ba}, \mathrm{SO}_{4}$ and possibly $\mathrm{Sr}$. The tendency for the isotopic compositions of the celestite and barite to merge in Fig. 3 suggests that solutions from these two systems did mix. For the Tamaulipas system the less radiogenic character of $\mathrm{Sr}$ in the celestite makes it likely that celestite formed when the barite-depositing solution was depleted in barite and mixed with a second solution containing $\mathrm{Sr}$ derived from local carbonate rocks.

The geologic environment in which such processes could occur is most likely to be a zone of relatively $\mathrm{SO}_{4}$-rich waters, perhaps associated with solution of gypsum in a backreef lagoonal facies. Sr-rich waters approaching such a zone from the backreef side would yield celestite deposits, whereas $\mathrm{Ba}-\mathrm{Sr}$ bearing solutions moving upward out of the basin could yield barite and possibly celestite deposits.

\section{CONCLUSIONS}

Our S- and Sr-isotopic analyses of celestite, barite and gypsum from the Mesozoic sedimentary basin of northern Mexico indicate that the celestite and barite deposits probably formed from elements derived from the basin during diagenetic processes. Whereas $\mathrm{Sr}$ in celestite appears to be derived dominantly from local carbonate rocks, the $\mathrm{Sr}$ and probably the $\mathrm{Ba}$ in the barite deposits appears to have come largely from basement-derived clastic rocks. Mass-balance estimates suggest that no more than $\sim 10 \%$ of the Sr available to be released from the carbonate rocks during diagenesis is trapped in celestite deposits. This, in turn, suggests that most Sr liberated by such diagenetic processes is dispersed into the sea.

\section{ACKNOWLEDGEMENTS}

Much of the field work on which this study is based was supported by Chemical Products Corp. and the Consejo de Recursos Minerales (Mexico). The strontium-isotope analyses were done in the Geochronology Laboratory 
of the Analytical Research Section of Conoco, Inc. Funding for the sulfur isotope measurements came from the National Research Council (Canada) and private funds. Sample preparation and data interpretation were supported, in part, by N.S.F. Grant EAR-7094894. We are very grateful to all of these organizations for their support. The manuscript has been improved by helpful reviews from J.L. Gray, K.C. Lohmann, B.H. Wilkinson, and J.L. Wilson.

\section{REFERENCES}

Blount, C.W., 1977. Barite solubilities and thermodynamic quantities up to $300^{\circ} \mathrm{C}$ and 1400 bars. Am. Mineral., 62: 942-957.

Butler, G.P., 1973. Strontium geochemistry of modern and ancient calcium sulphate minerals. In: B. Purser (Editor), The Persian Gulf, Springer, New York, N.Y., 471 pp.

Charleston, S., 1975. Stratigraphy, tectonics and hydrocarbon potential of the Lower Cretaceous, Coahuila Series, Coahuila, Mexico. Ph.D. Dissertation, University of Michigan, Ann. Arbor, Mich., 268 pp.

Claypool, G.E., Holser, W.T., Kaplan, I.R., Sakai, H. and Zak, I., 1980. The age curves of sulfur and oxygen isotopes in marine sulfate and their mutual interpretation. Chem. Geol., 28: 199-260.

Conklin, J. and Moore, C., 1977. Paleoenvironmental analysis of the Lower Cretaceous Cupido Formation, northeast Mexico. Tex. Bur. Econ. Geol., Rep. Invest. No. 89, pp. $302-323$.

Dasch, E.J. and Biscaye, P.E., 1971. Isotopic composition of strontium in Cretaceous-toRecent pelagic foraminifera. Earth Planet. Sci. Lett., 11: 201-204.

de Cserna, Z., 1956. Tectonica de la Sierra Madre Oriental de Mexico, entre Torreon y Monterrey. 20th Congr. Geol. Int., $87 \mathrm{pp}$.

de Cserna, Z., 1970. Mesozoic sedimentation, magmatic activity and deformation in northern Mexico. In: K. Seewald and D. Sundeen (Editors), The Geologic Framework of the Chihuahua Tectonic Belt. West Texas Geol. Soc., Midland, Tex., pp. 99-117.

Denison, R.E., Burke, Jr., W.H., Hetherington, E.A. and Otto, J.B., 1970. Basement rock framework of parts of Texas, southern New Mexico and northern Mexico. In: K. Seewald and D. Sundeen (Editors), The Geologic Framework of the Chihuahua Tectonic Belt. West Texas Geol. Soc., Midland, Tex., pp. 3-14.

Faure, G., 1977. Principles of Isotope Geology. Wiley, New York, N.Y., 464 pp.

Fulton III, R.B., 1975. Strontium in industrial minerals and rocks. In: S.J. Lefond (Editor), Industrial Minerals and Rocks. Am. Inst. Min., Metal. Pet. Eng., New York, N.Y., 1360 pp.

Humphrey, W.E., 1956. Tectonic framework of northeast Mexico. Gulf Coast Assoc. Geol. Soc. Trans., 6: 25-35.

Kellum, L.B., Imlay, R.W. and Kane, W.G., 1936. Evolution of the Coahuila Peninsula, Mexico, Part I. Relation of structure stratigraphy, and igneous activity to an early continental margin. Geol. Soc. Am. Bull., 47: 969-1008.

Kesler, S.E., 1977. Geochemistry of manto fluorite deposits, northern Coahuila, Mexico. Econ. Geol., 72: 204-218.

Kinsman, D., 1969. Interpretation of $\mathrm{Sr}^{2+}$ concentrations in carbonate minerals and rocks. J. Sediment. Petrol., 39: 486-508.

Krutak, P.R., 1965. Source areas of the Patula Arkose (Lower Cretaceous), Coahuila. J. Sediment. Petrol., 35: 512-517.

Kusakabe, M. and Robinson, B.W., 1977. Oxygen and sulfur isotope equilibria in the $\mathrm{BaSO}_{4}-\mathrm{HSO}_{4}^{-}-\mathrm{H}_{2} \mathrm{O}$ system from $110^{\circ}$ to $350^{\circ} \mathrm{C}$ and applications. Geochim. Cosmochim. Acta, 41: 1033-1041. 
Ohmoto, H., 1972. Systematics of sulfur and carbon isotopes in hydrothermal ore deposits Econ, Geol., 67: 551-578.

Parker, R.L., 1967. Data of geochemistry: In: Composition of the Earth's Crust, Ch.D. U.S. Geol. Surv., Prof. Pap. 440-D, 19 pp.

Peterman, Z.E., Hedge, C.E. and Tourtelot, H.A., 1970. Isotopic composition of Sr in seawater throughout Phanerozoic time. Geochim. Cosmochim. Acta, 34: 105-120.

Rickman, D. L., 1977. The origin of celestite (strontium sulfate) ores in the southwestern United States and northern Mexico. M.Sc. Thesis, N. Mex. Inst. Min. Technol., Socorro, N.M., $75 \mathrm{pp}$.

Salas, G.A., 1973. Geologra de los dépositos de celestita en la Sierra de Paila, Coahuila. Conv. Nac. Asoc. Ing. Minas, Metal., Geol. Mex., Mem. No. 10, pp. 287-294.

Strübel, G., 1967. Die hydrothermale Löslichkeit con Cölestin im System $\mathrm{SrSO}_{4}-\mathrm{NaCl}-$ $\mathrm{H}_{2} \mathrm{O}$. N. Jahrb. Mineral., Monatsh., 4: 99-108.

Temple, A.K. and Grogan, R.M., 1963. Manto deposits of fluospar, northern Coahuila, Mexico. Econ. Geol., 58: 1037-1054.

Thode, H.G. and Monster, J., 1965. Sulfur isotope geochemistry of petroleum, evaporites and ancient seas. In: A. Young and J.E. Galley (Editors), Fluids in Subsurface Environments, Am. Assoc. Pet. Geol., Mem. 4, pp. 367-377.

Thode, H.G., Monster, J. and Dunford, H.B., 1961. Sulfur isotope geochemistry. Geochim. Cosmochim. Acta, 25: 150-174.

Veizer, J. and Compston, W., 1974. ${ }^{87} \mathrm{Sr} /{ }^{86} \mathrm{Sr}$ composition of seawater during the Phanerozoic. Geochim. Cosmochim. Acta, 38: 1461-1484.

Weidie, A.E. and Martinez, J.D., 1970 . Evidence for evaporite diapirism in northeastern Mexico. Am. Assoc. Pet. Geol. Bull., 54: 655-657.

Wilson, J.C. and Pialli, G., 1977. A Lower Cretaceous shelf margin in northeastern Mexico. Tex. Bur. Econ. Geol. Rep. No. 89, pp. 286-294. 